\title{
Evaluation of the Analytical Performance of a Direct Quantitative Assay of Small Dense LDL
}

\author{
Mi-Na Lee ${ }^{1,2}$, Jong- \\ Ryol Kim ${ }^{1}$, Hee Jae \\ Huh $^{1,2}$, Soo-Youn Lee ${ }^{1,2}$, \\ Eun-Suk Kang ${ }^{1,2}$, and \\ Hyung-Doo Park ${ }^{1,2}$ \\ ${ }^{1}$ Department of Laboratory \\ Medicine and Genetics, \\ Samsung Medical Center; \\ ${ }^{2}$ Department of Laboratory \\ Medicine and Genetics, \\ Sungkyunkwan University \\ School of Medicine, Seoul, \\ Korea
}

\author{
Corresponding author: \\ Hyung-Doo Park \\ Department of Laboratory \\ Medicine and Genetics, Samsung \\ Medical Center, Sungkyunkwan \\ University School of Medicine, \\ 81 Irwon-ro, Gangnam-gu, Seoul \\ 135-710, Korea \\ Tel: +82-2-3410-0290 \\ Fax: +82-2-3410-2719 \\ E-mail: nayadoo@hanmail.net \\ pISSN: 1225-097X \\ elSSN: 2288-7261
}

\begin{abstract}
Background: Small dense low density lipoprotein (sdLDL) plays a critical role in the progression of coronary vascular disease. However, regardless of the accuracy of the analytical technique, routine measurement of LDL does not precisely ascertain LDL particle size. Therefore, we evaluated the performance of a direct quantitative assay of sdLDL that combines a precipitation method with filtration (Denka Seiken, Japan).

Methods: We evaluated the precision, linearity, carry-over, and sample stability of a sdLDL reagent. A reference interval was established, and method comparison was performed with the Lipoprint LDL system using polyacrylamide gel tube electrophoresis (Quantimetrix, USA).

Results: The within-run precision was $0.9 \%$ to $1.4 \%$, with a total precision of $3.2 \%$ to $3.5 \%$. The analytical measurement ranged from 4.1 to $101.3 \mathrm{mg} / \mathrm{dL}$. The calculated carry-over was negligible $(0.1 \%)$. Based on a comparison conducted using the Lipoprint LDL system, the median sdLDL concentration of 57 individuals with phenotype non-A was found to be significantly higher than that of 51 subjects with phenotype A ( 43 vs. $22 \mathrm{mg} / \mathrm{dL}, P<0.0001$ ). The levels in samples retested after storage showed more than $95 \%$ recovery when stored in a refrigerator $\left(5^{\circ} \mathrm{C}\right)$ for 2 weeks and at $-20^{\circ} \mathrm{C}$ or lower for 4 weeks. The reference interval of sdLDL was between 7.6 and $52.0 \mathrm{mg} / \mathrm{dL}$.

Conclusions: This method of sdLDL measurement showed good performance and can be easily applied to automated analysers in clinical laboratories.
\end{abstract}

(J Lab Med Qual Assur 2014;36:84-91)

Key Words : Small dense low density lipoprotein, Coronary disease, Reference values

Received February 3, 2014, Revision received April 16, 2014, Accepted May 7, 2014

\section{INTRODUCTION}

Elevated concentrations of low density lipoprotein (LDL) in blood positively correlate with the risk of coronary vascular disease (CVD). Circulating LDL particles have heterogeneous sizes, densities, and chemical compositions and can be categorized into two distinct phenotypes: phenotype $\mathrm{A}$ is associated with large, buoyant LDL particles, and phenotype B shows a predominance of small and dense particles [1]. Small dense LDL (sdLDL) particles are highly atherogenic owing to their higher penetration into the arterial wall, lower binding affinity for the LDL receptor, prolonged half-life, and lower resistance to oxidative stress [2-4]. Such distinctive biochemical features can lead to an inherited condition characterized by dyslipidaemia, insulin resistance, hypertension, and hypercoagulability, all of which increase the risk of CVD $[5,6]$.

sdLDL levels are conventionally measured by ultracentrifugation or gradient gel electrophoresis $[7,8]$, but these methods are unsuitable for routine analysis because they require expensive equipment, complicated procedures, and prolonged test times. Nuclear magnetic resonance imaging techniques have recently been developed to determine 
the size and number of LDL particles simultaneously [9], whereas lipoprotein analysis using high-performance liquid chromatography (HPLC) enables the measurement of lipid concentrations in various lipoprotein subfractions. However, these methods are too expensive for use in clinical laboratories. Moreover, HPLC is too labourintensive and time-consuming for routine clinical use [10].

The presence of sdLDL is part of an 'atherogenic lipoprotein phenotype' (lipid triad) that occurs with low high density lipoprotein (HDL) and high triglyceride (TG) concentrations, which frequently coexist without increased LDL [11]. Furthermore, current analytical techniques for LDL measurement, regardless of the accuracy, do not precisely characterize LDL particles. This imprecision is particularly evident when LDL particles are small because small LDL particles transport smaller amounts of cholesterol than large LDL particles do. Compared with patients with larger LDL particles, those with smaller LDL particles may need approximately 70\% more LDL particles to transport the same amount of cholesterol [12]. A distinct relationship between LDL particles size and CVD has been identified, providing reasonable evidence for the use of advanced lipoprotein testing such as sdLDL subfractioning and appraisal of LDL particle numbers in CVD risk assessment and treatment [13]. Hirano et al. [14〕 developed a simple two-step precipitation method for sdLDL quantitation comprising the removal of apolipoprotein B (ApoB) containing sdLDL free lipoprotein with heparin and magnesium followed by LDL measurement using the homogeneous method. The principle objective of the present study was to evaluate the analytical performance of the Seiken kit (sdLDL-EX; Denka Seiken, Tokyo, Japan) for the direct and rapid measurement of sdLDL.

\section{MATERIALS AND METHODS}

\section{Quantitative Determination of Small Dense LDL}

The principles of the procedure for quantitative sdLDL determination were based on the techniques previously described by Vandermeersch et al. [11]. Briefly, very low density lipoprotein (VLDL), intermediate-density lipoprotein, and large buoyant LDL and HDL were decomposed by a surfactant and sphingomyelinase in the first step. The cholesterol released from sdLDL was then degraded into water and oxygen by enzymes. In the next step, another surfactant released cholesterol only from sdLDL particles. The released cholesterol from sdLDL was then subjected to enzymatic reactions. Hydrogen peroxide produced in the reaction with cholesterol esterase and cholesterol oxidase develops a purplered colour with 4-aminoantipyrine and N-ethyl-n-(2hydroxy-3-sulfopropyl)-3-methylalinine in the presence of peroxidase. The entire reaction was completed within 10 minutes, and sdLDL concentration was calculated by measuring the change in absorbance at $600 \mathrm{~nm}$. The entire assay procedure was performed on a Modular P chemistry analyser (Roche Diagnostics, Mannheim, Germany). Aliquots of the serum were tested within 3 days of sampling or stored at $-20^{\circ} \mathrm{C}$ for less than 4 weeks and thawed immediately before the assay.

\section{LDL Subfraction and Other Biochemical Analyses}

LDL subfractions were separated with $3 \%$ polyacrylamide gel tube electrophoresis using the Lipoprint LDL system (Quantimetrix, Redondo Beach, CA, USA) according to the manufacturer's instructions. The system is approved by the U.S. Food and Drug Administration. Computer-assisted data analysis using an Artixscan 1100 scanner (Microtek Co., Carson, CA, USA) identified seven LDL bands by specific electrophoretic mobility relative to HDL when VLDL was at the origin and $\mathrm{HDL}$ was migrating in front [15]. LDL-1 and LDL-2 bands corresponded to large buoyant LDLs, whereas bands from LDL-3 to LDL-7 were composed of sdLDL particles. With the input of serum total cholesterol, the Lipoprint scoring system automatically categorizes electrophoretic profiles into those of phenotype A, with predominantly large LDLs (LDL-1 and LDL-2), and phenotype B, with predominantly small LDL (LDL-3 to LDL-7) subfractions [11]. The manufacturer provides the cut-off value for the two distinctive LDL subfraction phenotypes: mean LDL particle size of $\geq 268 \AA$ is categorized as phenotype A, $\leq 265 \AA$ defines the sdLDL-dominant phenotype 


\section{Journal of LABORATORY MEDICINE and QUALITY ASSURANCE \\ Mi-Na Lee et al • Evaluation of a Quantitative sdLDL Assay}

B, and values in between (265-268 $\AA$ ) are considered phenotype intermediate. Total cholesterol, TG, LDL, HDL, and glucose concentrations were measured using a Hitachi 7600 autoanalyser (Hitachi High-Technologies, Tokyo, Japan) or a Roche Modular D analyser (Roche Diagnostics).

\section{Precision}

The precision of the Seiken kit was assayed based on the guidelines from Clinical and Laboratory Standards Institute document EP5-A2 [16]. Testing was performed using a single lot of reagent, calibrators, and control materials. Low-level (range, 18.4 to $24.4 \mathrm{mg} / \mathrm{dL}$ ) and high-level (target range, 47.9 to $58.5 \mathrm{mg} / \mathrm{dL}$ ) quality control materials were provided by the manufacturer. Twenty aliquots at each level were assessed in sequence. After a preliminary precision evaluation, each aliquot was assayed in duplicate, for the two different concentrations, twice a day for 20 days ( 80 tests per single level). Calibration was performed before each run. Within-run and within-laboratory precision was calculated.

\section{Linearity}

Linearity was assessed according to Clinical and Laboratory Standards Institute document EP6-A [17]. Samples with five sdLDL concentrations were prepared by mixing high ( $101.3 \mathrm{mg} / \mathrm{dL})$ and low $(4.1 \mathrm{mg} / \mathrm{dL})$ levels of pooled commercial calibrators to create an intermediate concentration, and tests were performed in quadruplicate. The linearity of the results was determined with linear regression analysis.

\section{Comparison between Assays}

The method-comparison experiment between the Seiken kit and Lipoprint was based on the guidelines from Clinical and Laboratory Standards Institute document EP09A2-IR [18]. A serum-separating tube was used to draw serum from patients. One hundred and eight serum samples were analysed over 10 operating days, with calibration before every run. Each patient sample was assessed in Lipoprint and in duplicate using the Seiken kit. For method comparison between the assays, blood samples from the 108 patients were collected after 12 hours of overnight fasting. To separate the serum from the blood cells, we centrifuged venous blood samples at 2,000 $\mathrm{g}$ for 15 minutes at $4^{\circ} \mathrm{C}$. Freshly separated serum was used to determine LDL subfractions, and the remaining aliquots of the serum were used for sdLDL measurement.

\section{Sample Stability According to Storage Conditions}

Five samples with different sdLDL levels (11.1, 20.8, 41.8, 52.7, and $104.1 \mathrm{mg} / \mathrm{dL}$ ) were made by pooling patient serum samples. Seventeen aliquots of each level were produced, stored at four temperatures $\left(24^{\circ} \mathrm{C}, 5^{\circ} \mathrm{C}\right.$, $-20^{\circ} \mathrm{C}$, and $-70^{\circ} \mathrm{C}$ ) for five durations ( 1 day, 3 days, 1 week, 2 weeks, and 4 weeks), and tested in triplicate. Sample stability was calculated using the recovery rate of retested sdLDL concentrations compared to initial sdLDL concentrations and expressed as a percentage.

\section{Carry-Over}

We evaluated carry-over using two consecutive measurements of patient samples with high sdLDL levels (H1, H2), followed immediately by two measurements of patient samples with low sdLDL levels (L1, L2). Carryover was calculated using the equation (L1-L2)/(H2-L2) and expressed as a percentage [19].

\section{Establishment of Reference Interval}

The reference interval was established in accordance with the guidelines from Clinical and Laboratory Standards Institute document C28-A3c [20]. After excluding the outliers with a ratio $\mathrm{D} / \mathrm{R}$ method, we defined the reference interval as the 2.5 th percentile value to the 97.5th percentile value. Blood samples from healthy individuals who came to the health promotion centre at our hospital were collected after 12 hours of overnight fasting. A total of 270 healthy subjects (134 males and 136 females) with an age range of 22 to 83 years were included (Table 1). We excluded individuals with a history of hypertension, diabetes, CVD, or medication use, including use of lipid-lowering drugs. All subjects were free of hepatic, renal, thyroid, and malignant disease. In addition, we compared the sdLDL levels in 155 subjects 
Table 1. Demographic distribution of the subjects for reference range determination

\begin{tabular}{|c|c|c|c|}
\hline Variable & Male & Female & Total \\
\hline Age (yr) & $51(35-57)$ & $50(37-59)$ & $51(35-58)$ \\
\hline No. of subjects & 134 & 136 & 270 \\
\hline $31-50 \mathrm{yr}$ & 43 & 48 & 91 \\
\hline $51-70 \mathrm{yr}$ & 62 & 60 & 122 \\
\hline Total cholesterol (mg/dL) & $184(165-200)$ & $194(173-211)$ & $189(168-206)$ \\
\hline Triglycerides (mg/dL) & $99(72-130)$ & $72(56-101)$ & $84(63-118)$ \\
\hline $\mathrm{LDL}(\mathrm{mg} / \mathrm{dL})$ & $102(85-114)$ & $113(96-130)$ & $113(95-130)$ \\
\hline High density lipoprotein $(\mathrm{mg} / \mathrm{dL})$ & $54(47-60)$ & $69(60-77)$ & $60(50-70)$ \\
\hline
\end{tabular}

Values are presented as medians (interquartile range).

Abbreviation: LDL, low density lipoprotein.

with desirable lipid status to those of 115 individuals with borderline high lipid status [21]. This study was approved by the institutional review board of Samsung Medical Center, Seoul, Korea.

\section{Statistical Analysis}

Data are presented as the median (interquartile range) when not normally distributed. The slope and intercept for the linear regressed line between the sdLDL levels were calculated with linear regression analysis. A nonparametric comparison of the variables according to LDL subclass phenotype A versus non-A (including phenotype $\mathrm{B}$ and the intermediate phenotype) was performed using the t-test for normally distributed variables and the Mann-Whitney rank test for abnormally distributed variables. A $P$-value of $<0.05$ was considered statistically significant. The reference interval was calculated using MedCalc Statistical software ver. 12.3.2.0 (MedCalc Software, Mariakerke, Belgium).

\section{RESULTS}

Analysis of two sdLDL quality control materials using the Modular P analyser showed concentrations within the expected target ranges provided by the manufacturer (means, 21.3 and $54.2 \mathrm{mg} / \mathrm{dL}$, respectively). Within-run

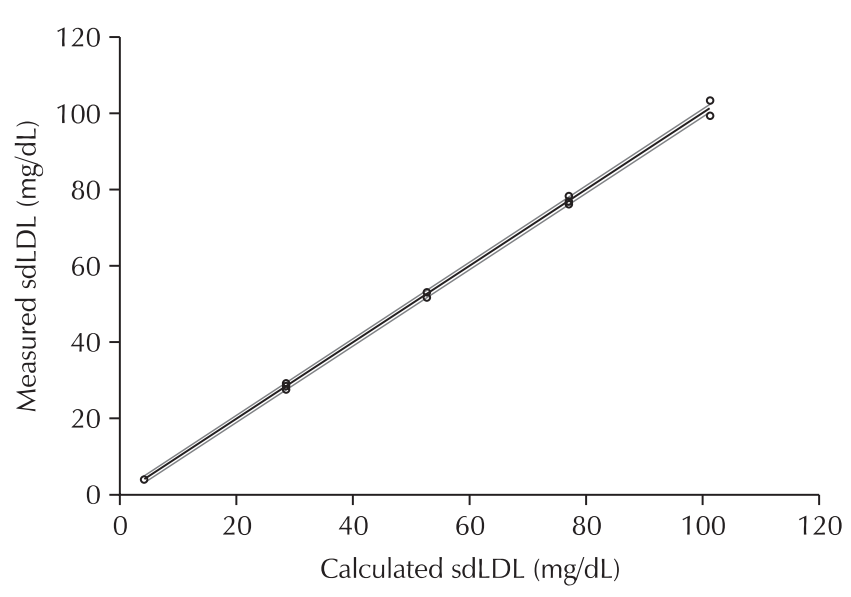

Fig. 1. Linearity of the small dense low density lipoprotein (sdLDL) quantitation assay in the range 4.1 to $101.3 \mathrm{mg} /$ $\mathrm{dL}$ obtained through serial dilution of high and low levels of commercial calibrators. Each level of the five intermediate concentrations was tested in quadruplicate. The solid line corresponds to the regression equation; the dashed lines indicate the $95 \%$ confidence interval for the regression equation.

precision was $1.4 \%$ for the low-level and $0.9 \%$ for the high-level controls, whereas total precision was 3.5\% for the low-level and 3.2\% for the high-level controls.

The analytical measurement ranged from 4.1 to 101.3 $\mathrm{mg} / \mathrm{dL}$ and demonstrated linearity throughout. Serial dilution of the calibrators provided a linear regression equation (linear fit, $y=1.0020 x+0.0469 ; F=17,031.96$; 


\section{Journal of LABORATORY MEDICINE and QUALITY ASSURANCE \\ Mi-Na Lee et al • Evaluation of a Quantitative sdLDL Assay}

$\left.P<0.001 ; R^{2}=0.9989\right)$, where $\mathrm{x}$ represents the expected sdLDL concentration, and y represents the measured sdLDL level (Fig. 1).

Table 2 compares sdLDL concentrations and other lipid biomarkers according to LDL phenotype. sdLDL concentrations of individuals with phenotype non-A were significantly higher than those of subjects with phenotype A $(P<0.0001)$ (Fig. 2). The $P$-values for comparisons of other lipid biomarkers, including total cholesterol, TG, LDL, HDL, and ApoB were also significant: $<0.001$ for

Table 2. Serum lipids and sdLDL according to LDL subclass phenotype $(\mathrm{n}=108)$

\begin{tabular}{lcc}
\hline \multicolumn{1}{c}{ Variable } & $\begin{array}{c}\text { Phenotype A } \\
(\mathbf{n}=51)\end{array}$ & $\begin{array}{c}\text { Phenotype } \\
\text { non-A }(\mathbf{n}=57)\end{array}$ \\
\hline Age (yr) & $60(55-66)$ & $56(49-64)$ \\
Female (\%) & $33.3(17)$ & $24.5(14)$ \\
Total cholesterol (mg/dL) & $153(140-187)$ & $191(162-224)^{*}$ \\
Triglycerides (mg/dL) & $83(71-114)$ & $150(108-213)^{\dagger}$ \\
LDL (mg/dL) & $85(69-108)$ & $118(97-145)^{\dagger}$ \\
HDL (mg/dL) & $56(48-69)$ & $41(36-48)^{\dagger}$ \\
Apolipoprotein B (mg/dL) & $76(62-85)$ & $104(85-114)^{\dagger}$ \\
sdLDL (mg/dL) & $22(16-27)$ & $43(28-58)^{\dagger}$ \\
\hline
\end{tabular}

Values are presented as percentage $(n)$ or median (interquartile range).

Abbreviations: sdLDL, small dense low density lipoprotein; LDL, low density lipoprotein; HDL, high density lipoprotein.

${ }^{\star} P<0.001 .{ }^{\dagger} P<0.0001$ comparing phenotype A vs. phenotype non-A.

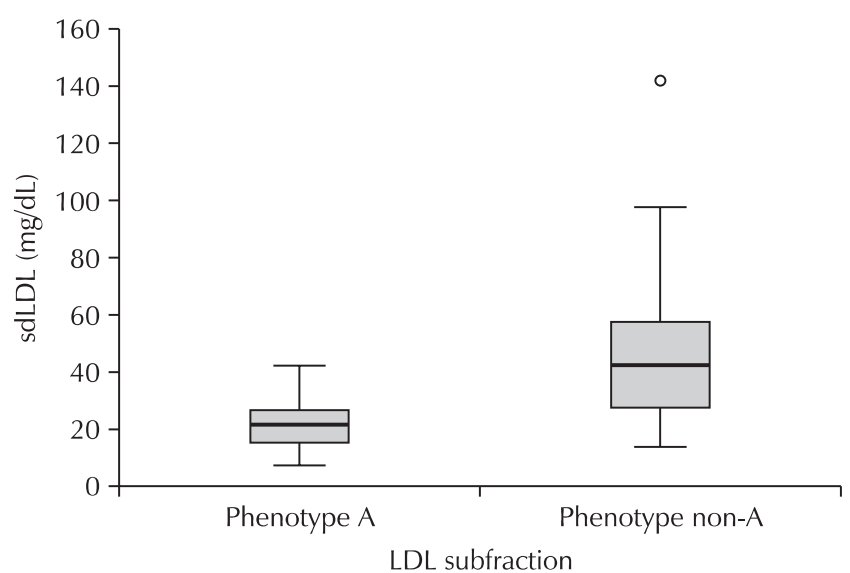

Fig. 2. Differences in small dense low density lipoprotein (sdLDL) according to LDL subclass phenotype. Phenotype A vs. phenotype non-A, $P<0.0001$. total cholesterol and $<0.0001$ for TG, LDL, HDL, and ApoB.

Compared to initial sdLDL concentrations, concentrations of samples retested after storage recovered more than $95 \%$ of the initial level when they were stored at room temperature $\left(25^{\circ} \mathrm{C}\right)$ for less than 3 days, in a refrigerator $\left(5^{\circ} \mathrm{C}\right)$ for 2 weeks, and at $-20^{\circ} \mathrm{C}$ or below for 4 weeks (Fig. 3). The calculated carry-over was negligible $(0.1 \%)$.

The lower (2.5th percentile) and upper (97.5th percentile) reference limits of sdLDL were $7.6 \mathrm{mg} / \mathrm{dL}$ and 52.0 $\mathrm{mg} / \mathrm{dL}$, respectively. Statistical analyses demonstrated significant differences in sdLDL concentration depending on gender $(P<0.01)$. The reference interval was 12.4 to $55.3 \mathrm{mg} / \mathrm{dL}$ in males and 5.5 to $46.9 \mathrm{mg} / \mathrm{dL}$ in females.

\section{DISCUSSION}

Compared with large LDL particles, sdLDL particles have a reduced affinity for LDL receptors. Consequently, sdLDL particles tend to be more readily concentrated and oxidized in the arterial wall [22]. In the past decade, the characterization and measurement of sdLDL subfractions have been investigated because of the critical role of these particles in atherosclerotic pathogenesis. In 2003, Hirano et al. [14] developed a precipitation methodology for the

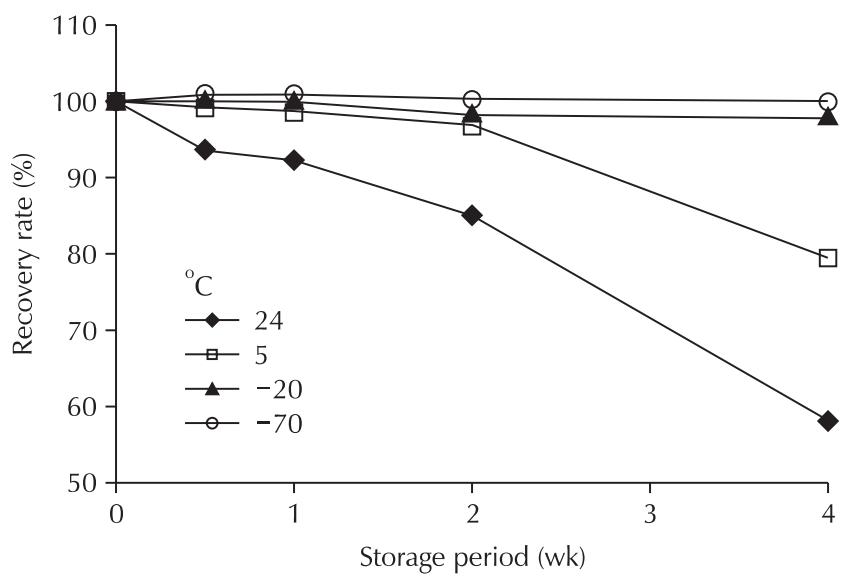

Fig. 3. Recovery rate (\%) of retested small dense low density lipoprotein (sdLDL) concentrations in stored samples compared with initial sdLDL concentrations according to temperature and duration of storage. 
quantitation of sdLDL and demonstrated that the method can easily be applied to autoanalysers. However, this method still demands manual preconditioning of samples. We evaluated a modified procedure using the commercially available Denka Seiken test kit, which permits direct measurement of sdLDL without sample preconditioning and is applied to automated analysers [11].

We used this direct method on a Roche Modular P analyser, achieving acceptable precision with coefficients of variation between $3.2 \%$ and $3.5 \%$ and a linear analytical measurement range of 4.1 to $101.3 \mathrm{mg} / \mathrm{dL}$. sdLDL concentrations of the phenotype non-A group were significantly higher than the phenotype A group. This outcome was the same for other lipid biomarkers, including total cholesterol, TG, LDL, HDL, and ApoB. The ideal sample matrix for precision and linearity is a pool of patient specimens. However, commercial control materials and calibrators were used in this study to evaluate precision and linearity because we could not acquire sufficient patient serum containing appropriate sdLDL levels.

When samples were stored above $-20^{\circ} \mathrm{C}$, the sdLDL concentration for retested samples was lower than the initial concentration. We tested another sample stored at $-20^{\circ} \mathrm{C}$ for 10 weeks and achieved a recovery rate of $83 \%$ (data not shown). Sample stability may be maintained when stored at $-20^{\circ} \mathrm{C}$ for less than 4 weeks, but we recommend that samples be deep-frozen per the manufacturer's recommendations to secure long-term stability. The manufacturer recommends storage at $-80^{\circ} \mathrm{C}$ or below for storage periods longer than 3 days, but we used $-70^{\circ} \mathrm{C}$, the lowest temperature of the refrigerator used in the study. Although stability was not tested after 1 month, we confirmed good stability of the samples stored at $-70^{\circ} \mathrm{C}$ for up to 1 month. Our sample stability results could be applied to laboratories that lack the equipment to store samples at $-80^{\circ} \mathrm{C}$. Improperly stored samples may yield falsely low sdLDL concentrations.

The desirable range of reference interval, 7.6 to 52.0 $\mathrm{mg} / \mathrm{dL}$ (range, 12.4 to $55.3 \mathrm{mg} / \mathrm{dL}$ in males; range, 5.5 to $46.9 \mathrm{mg} / \mathrm{dL}$ in females), in the present study was much narrower than those provided by the manufacturer (range, 5.1 to $60.8 \mathrm{mg} / \mathrm{dL}$ in 21 - to 44 -year-old males and 21- to 54-year-old females; range, 8.9 to $64.4 \mathrm{mg} / \mathrm{dL}$ in $45-$ to 75-year-old males and 55- to 75-year-old females). This discrepancy originates in the differences between the populations used in each study. Whereas subjects meeting Adult Treatment Panel (ATP) II guidelines with fasting glucose levels of $<126 \mathrm{mg} / \mathrm{dL}$ were included in the manufacturer's reference population, we included individuals meeting ATP III guidelines with fasting glucose levels of $<110 \mathrm{mg} / \mathrm{dL}$. Given the demonstrated population differences, we recommend that a reference interval be established separately in each clinical laboratory based on the guidelines used.

In conclusion, this precise and fully automated method for measuring sdLDL shows acceptable performance. Despite some limitations, our study provided information on the analytical performance of a method for direct measurement of sdLDL. This method can easily be applied to automated analysers in clinical laboratories to provide an effective measurement of sdLDL as a compelling and modifiable risk factor for CVD.

\section{ACKNOWLEDGEMENTS}

The sdLDL-EX Seiken kits used in this study were provided by Denka Seiken.

\section{REFERENCES}

1. Austin MA, King MC, Vranizan KM, Krauss RM. Atherogenic lipoprotein phenotype: a proposed genetic marker for coronary heart disease risk. Circulation 1990;82:495506.

2. Griffin BA. Lipoprotein atherogenicity: an overview of current mechanisms. Proc Nutr Soc 1999;58:163-9.

3. Berneis KK, Krauss RM. Metabolic origins and clinical significance of LDL heterogeneity. J Lipid Res 2002;43: 1363-79.

4. Verhoye E, Langlois MR; Asklepios Investigators. Circulating oxidized low-density lipoprotein: a biomarker of atherosclerosis and cardiovascular risk? Clin Chem Lab Med 2009;47:128-37.

5. Superko HR. Did grandma give you heart disease?: the 


\section{Journal of LABORATORY MEDICINE and QUALITY ASSURANCE}

Mi-Na Lee et al • Evaluation of a Quantitative sdLDL Assay

new battle against coronary artery disease. Am J Cardiol 1998;82(9A):34Q-46Q.

6. Grundy SM. Small LDL, atherogenic dyslipidemia, and the metabolic syndrome. Circulation 1997;95:1-4.

7. Nichols AV, Krauss RM, Musliner TA. Nondenaturing polyacrylamide gradient gel electrophoresis. Methods Enzymol 1986;128:417-31.

8. Swinkels DW, Hak-Lemmers HL, Demacker PN. Single spin density gradient ultracentrifugation method for the detection and isolation of light and heavy low density lipoprotein subfractions. J Lipid Res 1987;28:1233-9.

9. Otvos JD, Jeyarajah EJ, Bennett DW, Krauss RM. Development of a proton nuclear magnetic resonance spectroscopic method for determining plasma lipoprotein concentrations and subspecies distributions from a single, rapid measurement. Clin Chem 1992;38:1632-8.

10. Ito Y, Fujimura M, Ohta M, Hirano T. Development of a homogeneous assay for measurement of small dense LDL cholesterol. Clin Chem 2011;57:57-65.

11. Vandermeersch A, Ameye S, Puype D, Petitjean D, De Buyzere M, Langlois MR. Estimation of the low-density lipoprotein (LDL) subclass phenotype using a direct, automated assay of small dense LDL-cholesterol without sample pretreatment. Clin Chim Acta 2010;411:1361-6.

12. Cromwell WC, Otvos JD. Low-density lipoprotein particle number and risk for cardiovascular disease. Curr Atheroscler Rep 2004;6:381-7.

13. Koba S, Hirano T, Ito Y, Tsunoda F, Yokota Y, Ban Y, et al. Significance of small dense low-density lipoproteincholesterol concentrations in relation to the severity of coronary heart diseases. Atherosclerosis 2006;189:206-14.

14. Hirano T, Ito Y, Saegusa H, Yoshino G. A novel and simple method for quantification of small, dense LDL. J Lipid Res 2003;44:2193-201.
15. Hoefner DM, Hodel SD, O’Brien JF, Branum EL, Sun D, Meissner I, et al. Development of a rapid, quantitative method for LDL subfractionation with use of the Quantimetrix Lipoprint LDL System. Clin Chem 2001;47:26674.

16. Tholen DW KA, Kennedy JW, Krouwer JS, Meier K. Evaluation of precision performance of quantitative measurement methods: approved guideline-second edition. NCCLS documalet EP5-A2. 2nd ed. Wayne (PA): Clinical and Laboratory Standards Institute, 2004.

17. Tholen DW KM, Astles JR, Caffo AL, Happe TM, Krouwer J, Lasky F. Evaluation of the linearity of quantitative measurement procedures: a statistical approach: approved guideline. NCCLS documalet EP6-A. Wayne (PA): Clinical and Laboratory Standards Institute, 2003.

18. Wayne P. Method comparison and bias estimation using patient samples: approved guideline-second edition. CLSI documalet EP09-A2-IR. 2nd ed. Wayne (PA): Clinical and Laboratory Standards Institute, 2010.

19. Broughton PM. Carry-over in automatic analysers. J Automat Chem 1984;6:94-5.

20. Wayne P. Defining, establishing, and verifying reference intervals in the clinical laboratory: approved guidelinethird edition. CLSI documalet C28-A3c. 3rd ed. Wayne (PA): Clinical and Laboratory Standards Institute, 2008.

21. Expert Panel on Detection, Evaluation, and Treatment of High Blood Cholesterol in Adults. Executive Summary of The Third Report of The National Cholesterol Education Program (NCEP) Expert Panel on Detection, Evaluation, And Treatment of High Blood Cholesterol In Adults (Adult Treatment Panel III). JAMA 2001;285:2486-97.

22. Rizzo M, Berneis K. Low-density lipoprotein size and cardiovascular prevention. Eur J Intern Med 2006;17:7780. 


\section{작고 밀도가 높은 저밀도지단백 정량검사의 성능 평가 이미나 ${ }^{1,2}$ • 김종열 ${ }^{1}$ 허희재 ${ }^{1,2} \bullet$ 이수연 ${ }^{1,2}$ - 강은숙 ${ }^{1,2} \bullet$ 박형두 $^{1,2}$ \\ ${ }^{1}$ 삼성서울병원 진단검사의학과, ${ }^{2}$ 성균관대학교 의과대학 진단검사의학교실}

배경: 작고 치밀한 저밀도지단백(small dense low density lipoprotein, sdLDL)은 심혈관질환의 진행에 주요인자로 알려져있다. 통상적인 LDL 측정법은 분석법의 정확도와 관계없이 LDL 입자 크 기를 잘 반영하지 못한다. 이에 저자들은 $\mathrm{sdLDL}$ 을 직접 정량적으로 측정할 수 있는 침전법을 이용한 sdLDL 시약(Denka Seiken, Japan)의 분석능에 대한 평가를 시행하였다.

방법: sdLDL 시약에 대하여 정밀도, 직선성, 잔효, 검체안정성 등을 평가하였다. 또한 참고범위를 설 정하였으며, polyacrylamide gel tube electrophoresis (Lipoprint LDL system; Quantimetrix, USA) 검사법과의 상관성을 평가하였다.

결과: 검사내정밀도와 총정밀도의 변이계수는 각각 0.9-1.4\%, 3.2-3.5\%이었다. 분석측정범위는 4.1-101.3 mg/dL이었으며, 잔효는 0.1\%로 거의 관찰되지 않았다. Lipoprint 방법으로 표현형이 A가 아닌 57명의 sdLDL 농도가 표현형 A인 51명 그룹보다 현저하게 높았다(43 vs. $22 \mathrm{mg} / \mathrm{dL}$, $P<0.0001)$. 시약 안정성 평가에서는 보관 전 농도와 비교하였을 때, $5^{\circ} \mathrm{C}$ 에서 2 주 보관 및 $-20^{\circ} \mathrm{C}$ 이하에서 4주 보관한 뒤 측정한 $\mathrm{sdLDL}$ 농도가 $95 \%$ 이상 회복되는 것을 확인하였다. 참고범위는 $7.6-52.0 \mathrm{mg} / \mathrm{dL}$ 로 결정되었다.

결론: $\mathrm{sdLDL}$ 정량검사는 적절한 검사성능을 보였을 뿐만 아니라, 간편하게 자동화검사장비에 적용 할 수 있어 임상검사실에서 유용하게 사용될 수 있을 것이다.

(J Lab Med Qual Assur 2014;36:84-91)
교신저자: 박형두

우)135-710 서울시 강남구 일원로 81, 성균관대학교 의과대학 삼성서울병원 진단검사의학교실

Tel: 02)3410-0290 Fax: 02)3410-2719 E-mail: nayadoo@hanmail.net

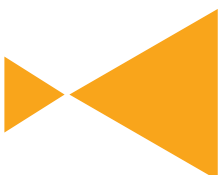

Journal of LABORATORY MEDICINE and

QUALITY ASSURANCE 